\title{
Telework During Pandemic: Comparing Readiness between Local and Central Government Employees
}

\author{
Muhamad Azami Nasri \\ Department of Public Administration, Faculty of Administration Science, Universitas Indonesia \\ (Email: azaminasri10@gmail.com) \\ Muhammad Nurdin Alamsyah \\ Doni Ramadhan \\ Reza Fathurrahman
}

\begin{abstract}
Employing Holt, et al.'s (2007) Readiness for Change Theory, this study investigates the readiness level among the local and central government employees to embrace the unanticipated Telework policy during the COVID-19 pandemic. For this purpose, individual perceptions of 383 respondents (237 central and 146 local government employees) were analyzed using the Mann-Whitney test. The statistical results reveal that the respondents who represent central government employees show significantly higher readiness level than their colleagues from the local regions. Further analysis at the dimensional level provides further explanation for this: It is evident that the central civil servant respondents show their superiority over local civil servant respondents on the three aspects, namely the level of understanding about the urgency of changing the way of working to telework, confidence in learning new skills to support telework, and awareness of the potential benefits of telework for themselves respectively. Interestingly, there is no significant difference between the two groups in terms of managerial support.
\end{abstract}

\section{Keywords:}

readiness for change; telework; COVID-19

\section{Introduction}

The world has been shocked by the emergence of Coronavirus Disease (COVID-19) since early 2020 which brings significant impact to various strategic sectors, including economy, health, politics, and security (Mustajab, et al. 2020). Beyond that, COVID-19 has significantly affected the governance system and the provision of public services to the general citizens, partly due to changes in the way and working patterns of Government Employees (Paudel, 2020). No one ever expected before that the "Work From Home" (also known as 'telework') policy could be implemented in most government agencies by 2020 . 
In August 2019, the Ministry of Administrative Reform (Kemen PAN-RB) issued a discourse on flexible working arrangement for government employees by utilizing technology (Fajar, 2019). The Deputy for Human Resources Apparatus of the Kemen PAN$\mathrm{RB}$, Setiawan Wangsaatmaja, explained that this idea came up considering the fact that as many as 572,000 Government Employees in 2019 are already technologically literate. It is estimated to continue growing by 200,000 formations every year, until it reaches $50 \%$ of Government Employees in 2024 and thus becoming the foundation for Indonesian future bureaucracy (Sukmana, 2019). It is also consistent with the results of 'We Are Social Survey': 175.3 million people or about $64 \%$ of Indonesia's population currently using the internet on all types of devices (Kemp, 2020).

The discourse on teleworking policy was also conducted as an integrated effort to realize the Smart ASN (Smart Government Employees) profile as a reward for Government Employees with good performance (PRC, 2019). The minister of Kemen PAN-RB (2018-2019), Syafruddin, explained that the main source of inspiration for developing the WFH scheme was from the best practice in Australia which allows selected high-performing employees to work from home every Wednesday. Furthermore, he also explained that the teleworking option provided for government employees is not for basic service officers or those who require physical presence (Rahma, 2019). Commissioner Rudiarto Suwarwono from the State Civil Apparatus Commission divides the forms of flexible working into three models, namely workplace flexibility, working time flexibility, and task flexibility. Before the pandemic came, the initial stage of this telework policy was planned to begin as an experiment involving 1,000 civil servants working at the Ministry of National Development Planning (Bappenas) with a work flexibility scheme by early 2020 (Ulya, 2019).

Mukaromah (2019) highlights the pros and cons of the teleworking, such as the minister of Kemen PAN-RB, Tjahjo Kumolo who supports Government Employees' work flexibility plan without having to work in the office and Chairman of the Association of Governments of Indonesia (APKASI), Abdullah Azwar Anas who perceives this idea as a government's response to the global work flexibility trend. On the other hand, there are also resistances shown by a number of local governments including Padang, North Aceh, Gayo Lues, and Lhokseumawe on the grounds of the urgent need to provide better facilities in advance for the entire region prior to telework implementation (Mukaromah, 2019). 
The concept of teleworking has evolved from time to time, however it is generally interpreted as a flexible working arrangement given to individual employees to do whole or part of their work from a separate location, outside office, with the help of information and communication technology (De Vries, et al., 2019; Baruch, 2001). In this study, teleworking can be used interchangeable with the terms 'work from home' or 'flexible working arrangement'. The Ministry of Administrative Reform called it 'work from home' (WFH). The term WFH itself is used in order to adjust the government employees' work system to prevent the spread of COVID-19 in government agencies.

Previous studies have shown that the implementation of WFH policy has bring both positive and negative impacts for the government and its employees. Wardhana (2020) found that WFH policy could reduce the operational burden of the office where the cost of office maintenance such as room rental, office assets, water, electricity, and others, while for employees it is cost efficient because they no longer need to spend extra money for transportation, appearance, and other related expenses. Moreover, earlier studies also show the following benefits of WFH, namely reducing work-life conflict, reducing stress levels, and reducing congestion and air pollution (Handy \& Mokhtarian, 1996; Fonner \& Roloff, 2010); increased job satisfaction (Gurstein, 2001); increase time with family (Ammons \& Markham, 2010); reducing unnecessary communication (Khalifa \& Davison, 2000); and creating plenty of time for employees to prepare for their work (Morgan, 2004).

Krisyohana (2020) argues that the implementation of WFH in public sector may produce various problems as a result of the one-size-fits-all national Standard Operating Procedure (SOP), unforeseen implementation of WFH in response to the conditions of the COVID-19 pandemic, and inadequate system to optimally support the provision of online public services. In addition, she also emphasizes that in absence of the required legal basis regulating the number of office hours during WFH has contributed to make the situation unclear, less motivated, and stressful as they feel overburdened with continuous multitasking and distraction.

Finally, there are also problems related to limited technology coverage and weak internet connections (Suarlan, 2018). The existence of poor infrastructure will undoubtedly become a big challenge for the government in implementing the WFH policy. Previous studies also show that WFH may lead to social isolation and lack of communication with colleagues, 
limit the alignment with organizational values and goals, and loss of important working tools (Baruch, 2002; Cooper \& Kurland, 2002; Wilson \& Greenhill, 2004; Ammons \& Markham, 2010; Ipsen \& Kirchner, 2020).

The readiness shown by employees to make changes is a key to the organizational success (Abdurrohman \& Kadiyono, 2019). It is also in line with their individual preparedness to determine whether the implementation of WFH policy will continue to run within the productivity corridors or not. If the civil servants are not supportive towards change then there is a greater possibility that they may not be able to fulfill the demand and may feel overburdened by the WFH policy (Hanpachern, Morgan, \& Griego, 1998).

\section{Graph 1.}

\section{Digital Competitiveness Index 2020 Score}

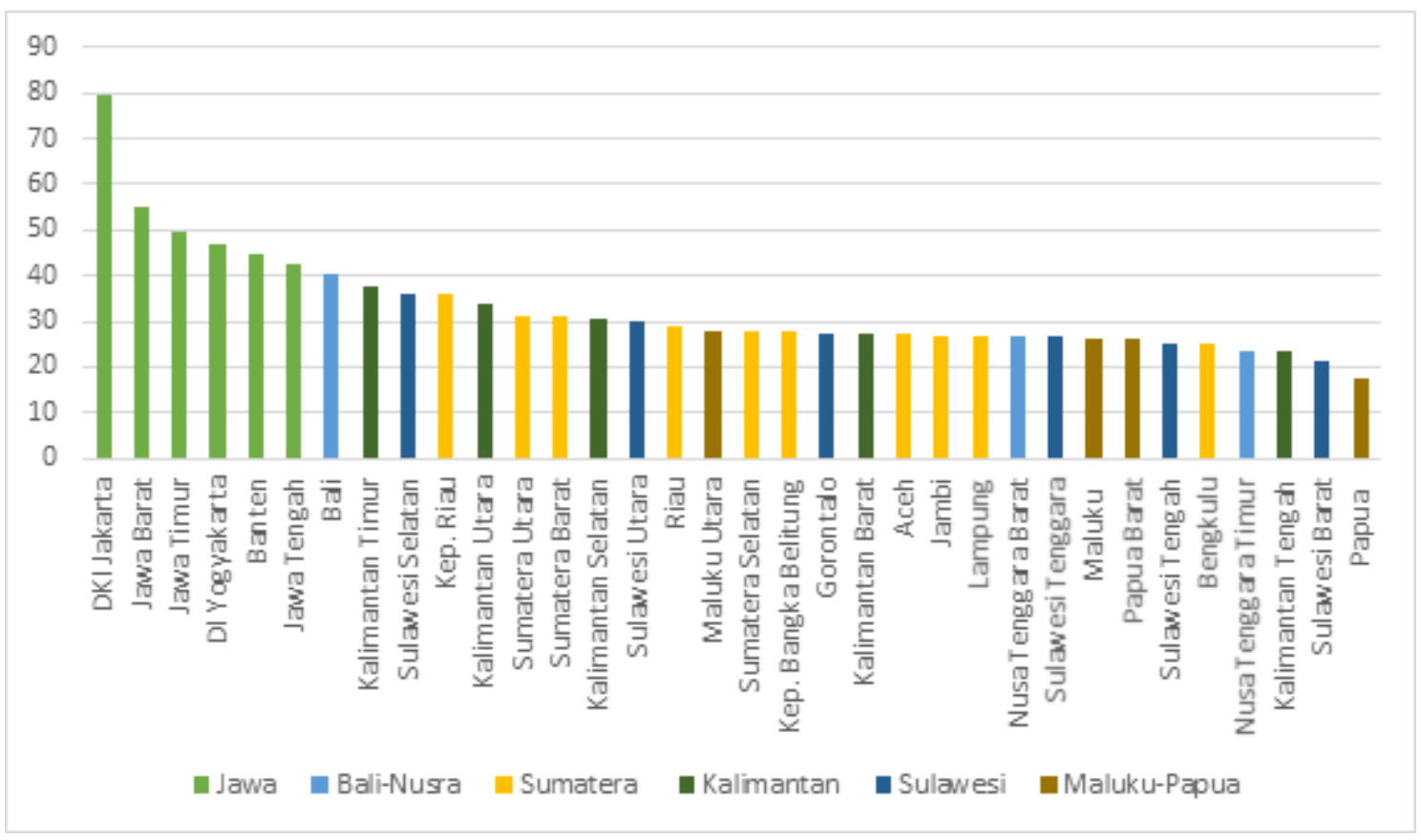

Source: East Ventures (2020). Re-Processed by Researchers.

Graph 1 summarizes the results of a recent study on the Digital Competitiveness Index 2020 conducted by East Ventures (2020). The results of the study show the fact that DKI Jakarta (79.7 points) and five other provinces in Java in a row, namely West Java (55), East Java (49.7), Yogyakarta (46.7), Banten (44.8), and Central Java (42.6) are listed as the six provinces with the best digital development, both from input aspects (utilization of technology and information), output (productivity generated), and support (facilities, financial infrastructure, 
regulation, and capacity of local government) when compared to other provinces outside java (East Ventures, 2020). This finding supports an argument that geographical location, e.g. inside or outside Java island; mountain or hill area, does matter. For example, civil servants working at the Banjarnegara regional government may experience network-related constraints in carrying out WFH policy because of Banjarnegara's geographical location that is mostly within mountainous areas (Rigianti, 2020). This fact is very challenging given the proportion of regional government employees who dominate the Indonesian civil servants population $(77.03 \%$ or $3,174,570$ employees), meanwhile the central government employees are only amounted to $22.97 \%$ or 946,606 employees (Badan Kepegawaian Negara, 2020). Reflecting from this fact, researchers are interested to investigate whether there is a difference in term of readiness between central government employees and regional government employees in implementing WFH policy. We propose the following hypothesis:

H0: There is no difference in readiness between the readiness of Central government employees and Regional government employees in implementing WFH policy

$\mathrm{H} 1$ : There is a difference in readiness between the readiness of Central government employees and Regional government employees in implementing WFH policy

Readiness for organizational change is defined as a comprehensive attitude that is influenced simultaneously by content (what is being changed), processes (how changes are applied), context (the circumstances in which changes are taking place), and individuals (characteristics of actors who are required to change). At individual level, readiness reflects the extent to which individuals are cognitively and emotionally inclined to accept, support, and adopt a deliberate change plan to change the status quo (Holt, Armenakis, Feild, \& Harris, 2007).

According to Holt, Armenakis, Feild, and Harris (2007) individual readiness is defined as a multidimensional concept influenced by individual beliefs. The concept was developed by reviewing 32 instruments of measuring readiness for organizational change plus 131 other related sources, including books, articles, research, reports, and scientific manuscripts. Holt, Armenakis, Field, and Harris (2007) also completed their literature review works with the results of semi-structured interviews with 15 senior to mid-level managers, as well as by distributing open questionnaires to $60 \mathrm{mid}$ - and lower-level managers. Based on a thorough analysis of these sources, Holt, Armenakis, Field, and Harris (2007) obtained the final results 
and revealed the most important 4 dimensions related to the concept of individual readiness, namely:

\section{Appropriateness}

According to Holt, Armenakis, Feild, and Harris (2007), appropriateness refers to the level of individual confidence that proposed changes are necessary, appropriate to the situation, and beneficial to the organization. This is in line with Holt and Vardaman's definition of appropriateness (2013) which is the belief that certain changes are appropriate to address the situation of a particular organization that is being addressed. In Holt, Armenakis, Feild, and Harris' research (2007), the dimensions of appropriateness consisted of two themes which are discrepancy and organizational valence. According to Holt, Armenakis, Feild, and Harris (2007), discrepancy refers to the level of individual belief that a change initiative is necessary because it is a necessity and there are legitimized reasons for making such a change initiative. Meanwhile, related to the theme of organizational valence, Holt, Armenakis, Feild, and Harris (2007) stated that organizational valence refers to the level of individual belief that change will benefit the organization. The focus of organizational valence includes the benefits of change, improving efficiency, and the suitability between change and organizational goals. There are three indicators in this dimension, namely the individual's belief that work from home is necessary by the organization, the individual's belief that work from home is appropriate to the situation faced by the organization, and the individual's belief that work from home will be beneficial to the organization in the long term.

\section{Management support}

According to Holt, Armenakis, Feild, and Harris (2007), management support refers to the level of individual confidence that leaders in the organization are committed to and support the implementation of change. This dimension of management support is also supported by Armenakis and Harris's assertion (2002) that change requires a commitment to institutionalization, because if there is no clear support from leaders, then individuals within the organization tend to be skeptical and inactive to support the implementation of change. According to Holt, Armenakis, Feild, and Harris (2007), management support represents a change process perspective in individual readiness models, therefore the role of leaders is closely related to the steps taken during the change. This is in line with van de Ven and Poole's opinion (1995), which revealed that organizational leaders often introduce broad goals and 
changes deliberately to realize specific goals. There are three indicators in this dimension, namely that the leader of the organization is committed to carrying out work from home, the leader of the organization participates in communicating the plan of implementation of work from home, and the leader of the organization provides support to employees in carrying out work from home.

\section{Change-specific efficacy}

According to Holt, Armenakis, Feild, and Harris (2007), change-specific efficacy or socalled self-efficacy refers to an individual's level of confidence that they have the ability and skills to carry out tasks and activities when changes are implemented. The change-specific efficacy dimension reflects the extent to which the individual feels confident of performing well and doing his job successfully. According to Holt, Armenakis, Feild, and Harris (2007), change-specific efficacy represents the perspective of individual attributes in readiness models related to individual characteristics within the organization. The change-specific efficacy dimension is also related to the definition of readiness from Holt, Helfrich, Hall, and Weiner (2010) which states the extent to which the individuals involved are prepared, motivated, and technically capable of implementing changes. Based on this explanation, it can be known that the change-specific efficacy dimension is related to other dimensions, the most visible is management support in the form of support, motivation, as well as example by the leader to his subordinates. There are two indicators in this dimension, namely that individuals feel able to carry out tasks and activities related to the implementation of work from home, and individuals have the skills to carry out tasks and activities related to the implementation of work from home.

\section{Personal valence}

According to Holt, Armenakis, Feild, and Harris (2007), personal valence or so-called personally beneficial refers to the individual's level of belief that the proposed changes benefit individuals personally. Armenakis and Harris (2002) stated that individuals will assess the positive and negative outcomes of changes for themselves, the fairness of the change initiatives, and how individuals are treated during the process of change being implemented. Individual resistance to organizational change will arise if an individual's personal interests are threatened. Personal Valence in Holt, Armenakis, Field, and Harris research (2007) represents the perspective of individual attributes in readiness models related to individual 
attributes within the organization. This dimension is also supported by Vakola's statement (2014) which states that individual readiness levels may differ due to cost and benefit considerations arising from organizational changes. There are three indicators in this dimension, namely that the implementation of work from home is beneficial for the personal relationships of individuals within the organization, the implementation of work from home is beneficial for the social status of individuals within the organization, and the implementation of work from home is beneficial for the employment opportunities of individuals within the organization.

Considering the explanation provided above, in order to gain a better understanding of the phenomenon being investigated, statistical tests were also conducted to find out whether there is a difference in the score of the four dimensions between the central and regional government employees in implementing WFH policy.

\section{Methods}

The approach used in this study is a quantitative approach. This study used the withdrawal of non-probability samples i.e. quota sampling. Non-probability sample withdrawal techniques are performed given the limitations in the preparation of sample frameworks or the presumption of samples in the population. Quantitative data collection techniques were conducted by surveying through questionnaire instruments whose dissemination is carried out online using SurveyMonkey platform with the criteria of respondents include government employees who are currently doing or already experienced WFH. The dissemination of questionnaires conducted from 7 to 10 August 2020 resulted in 428 respondents filling out questionnaires with as many as 383 respondent data can be processed and 45 respondent data cannot be processed. The reasons for the elimination of the respondents are due to the discrepancy in the filling of positions, discrepancies in the reasons for reinforcing open answers, and discrepancies in the filling of workplace agencies. Univariate data analysis was employed because it uses one variable namely the readiness for change level among central and regional government employees in implementing WFH policy and the type of univariate analysis used is frequency distribution, concentration size, and data dissemination. The data was processed using SPSS software (Statistical Product and Service Solution). 4-point Likert Scale was used to determine the level of readiness, including: 
Strongly Agree, Agree, Disagree, and Strongly Disagree. The formula used to test two groups of samples is Mann-Whitney to test whether or not the score difference exists between the two variables.

\section{Results and Discussion}

This chapter summarizes the results of the analysis to answer the predetermined research question: "Is There a Difference in Readiness between Central government employees and Regional government employees in Implementing WFH policy?".

Table 1.

Readiness Level Of Central Government Employees And Regional Government Employees In Implementing WFH Policy

\begin{tabular}{|l|c|c|c|c|}
\hline \multirow{2}{*}{$\begin{array}{l}\text { Government Agencies } \\
(\mathrm{n}=383)\end{array}$} & \multicolumn{3}{|c|}{ WFH Readiness Level } & \multirow{2}{*}{ Total } \\
\cline { 2 - 4 } & Low & Moderate & High & \\
\hline $\begin{array}{l}\text { Central government employees } \\
(\mathrm{n}=237)\end{array}$ & $1,7 \%(4)$ & $48,5 \%(115)$ & $49,8 \%(118)$ & $100 \%$ \\
\hline $\begin{array}{l}\text { Regional government employees } \\
(\mathrm{n}=146)\end{array}$ & $2 \%(3)$ & $74 \%(108)$ & $24 \%(35)$ & $100 \%$ \\
\hline
\end{tabular}

Source: Processed by Researchers, 2020

Table 1 summarizes the readiness level shows by central government employees and regional government employees in implementing WFH. Based on the analysis, the majority of respondents who are working in central government agencies show high readiness, which is equal to $49.8 \%$ or 118 respondents. The remaining $48.5 \%$ or 115 respondents show moderate readiness, and $1.7 \%$ or 4 respondents has low readiness. Different results were shown by regional government employee respondents, where the majority of respondents $(74 \%)$ indicated moderate readiness in implementing WFH policy, while only $24 \%$ of respondents had high readiness and the remaining $2 \%$ showed a low readiness level. Consistent with these findings, statistical test results also show a difference in the readiness level between central and regional government employees to embrace the WFH policy implementation.

Table 2.

The Difference Test of WFH Readiness Level 


\begin{tabular}{|l|l|}
\hline & WFH Readiness Level \\
\hline Mann-Whitney U & 12878.00 \\
Wilcoxon W & 23609.000 \\
Z & -4.890 \\
Asymp. Sig. (2-tailed) & .000 \\
\hline
\end{tabular}

Source: Processed by Researchers, 2020

As summarize under Table 2 above, it is revealed that the significance of the Mann Whitney U Test result between the central government employees variable and the regional government employees is $0.000<0.05$, so it can be concluded that $\mathrm{H} 0$ is rejected; there are differences in individual readiness in implementing Work From Home (WFH) policy between central government employees and regional government employees. To gain further understanding of the findings, the researchers conducted further analysis of the four theoretical dimensions that contributed to the total score scoring of Readiness for Change, namely: Appropriateness, Management Support, Change-Specific Efficacy, and Personal Valence.

Table 3.

Appropriateness Dimension of Central Government Employees and Regional Government Employees

\begin{tabular}{|l|l|l|l|l|}
\hline \multirow{2}{*}{$\begin{array}{l}\text { Government Agencies } \\
(\mathrm{n}=383)\end{array}$} & \multicolumn{3}{|l|}{ Dimension Level of Appropriateness } & Total \\
\cline { 2 - 4 } & Low & Moderate & High & \\
\hline $\begin{array}{l}\text { Central government employees } \\
(\mathrm{n}=237)\end{array}$ & $1 \%(3)$ & $51 \%(121)$ & $48 \%(113)$ & $100 \%$ \\
\hline $\begin{array}{l}\text { Regional government employees } \\
(\mathrm{n}=146)\end{array}$ & $3 \%(5)$ & $76 \%(111)$ & $21 \%(30)$ & $100 \%$ \\
\hline
\end{tabular}

Source: Processed by Researchers, 2020

Appropriateness dimension according to Holt et al., (2007), refers to the level of individual belief that proposed changes are necessary, appropriate to the situation, and beneficial to the organization. Based on the results of the research survey as summarized in Table 3, 48\% of central government employee respondents have a high level of confidence that WFH Policy is absolutely necessary, while $51 \%$ of respondents have moderate confidence in the urgency of implementing the WFH policy. Only $1 \%$ of respondents did not really believe in the importance of changing from Work at the Office to Work From Home. Meanwhile, 
regional government employee respondents in aggregate are also dominated by those with moderate confidence levels (76\%), high (21\%), and low appropriateness (3\%) to implement WFH policy at this time.

Table 4.

The Different Test of Appropriateness of Central Government Employees and Regional Government Employees

\begin{tabular}{|l|l|}
\hline & Appropriateness Dimension \\
\hline Mann-Whitney U & 12471.000 \\
Wilcoxon W & 23202.000 \\
Z & -5.388 \\
Asymp. Sig. (2-tailed) & .000 \\
\hline
\end{tabular}

Source: Processed by Researchers, 2020

Based on the table shown above, it is known that the significance value of the Mann Whitney U Test result between the Central government employees variable and the Regional government employees is $0.000<0.05$ on the dimension of Appropriateness, so it can be concluded that $\mathrm{H} 0$ is rejected; there is a difference in individual readiness in the dimensions of Appropriateness in implementing WFH between Central Government Employee respondents and Regional Government Employee respondents. Based on the results of the data process, it can be concluded that statistically Central Government Employee respondents have a higher level of confidence compared to Regional Government Employee respondents in assessing the urgency of the implementation of WFH policy as well as their benefits for the agencies in which they work.

Assessment of the urgency of WFH implementation, reflecting from the respondents' answers toward question item number 5 regarding "Rational reasons in the implementation of WFH", 83\% or 121 respondents of Regional government employees "Agree" that they realize there are rational and strong reasons to implement $\mathrm{WFH}$, while for central government employee respondents only $65 \%$ or 154 respondents who "Agree" on the matter. However, it is also found that central government employee respondents answered "Strongly Agree", which is $31,2 \%$ or 74 respondents who strongly believe that there are rational reasons in the implementation of WFH, while only $6.1 \%$ or 9 respondents of Regional Government Employee "Strongly Agree" on this.

Central government employee respondents' approval is consistently also seen in the response they give to question item number 1 regarding the "Benefits of WFH implementation 
for the agencies in which they work" where $82 \%$ of respondents stated "Beneficial" (68\%) or "Very Beneficial" (16\%). In addition, the approval of the majority of Central Government Employee respondents (61\% "Agree" and 19\% "Strongly Agree") on question item number 4 concerning "efficiency improvement for agencies as a result of the implementation of WFH". This efficiency occurs due to a reduction in office costs which include, electricity usage costs and internet usage costs (Mungkas, 2020). It is also similar to Taufik \& Warsono's opinion (2020) that the covid-19 pandemic has changed the paradigm of the civil servant's working system to be more effective and efficient, as well as more results-oriented than procedural.

Furthermore, the approval of the majority of Central Government Employee respondents (19\% "Agree" and 49\% "Strongly Agree") to question item number 6 regarding the "long-term benefits of WFH implementation for individuals". The long-term benefits of this WFH policy are related to the development of individual capabilities using information technology. With WFH, individuals in the organization are encouraged to be able to make adjustments to the use of technology. Yulianto (2020) states that WFH demands civil servants to be able to adapt and keep up with the demands of change, especially from those who are not tech savvy, to civil servants with good digital literacy. This literacy digital competency framework consists of ASN digital insights, ASN digital skills, and ASN digital behavior (Rumata \& Nugraha, 2020).

Table 5.

Management Support Dimension of Central and Regional Government Employees

\begin{tabular}{|l|c|c|c|c|}
\hline \multirow{2}{*}{$\begin{array}{l}\text { Government Agencies } \\
(\mathrm{n}=383)\end{array}$} & \multicolumn{2}{|l|}{ Management Support Dimension Level } & \multirow{2}{*}{ Total } \\
\cline { 2 - 5 } & Low & Moderate & High & \\
\hline $\begin{array}{l}\text { Central government employees } \\
(\mathrm{n}=237)\end{array}$ & $2,1 \%(5)$ & $48,9 \%(116)$ & $48,9 \%(116)$ & $100 \%$ \\
\hline $\begin{array}{l}\text { Regional government employees } \\
(\mathrm{n}=146)\end{array}$ & $1 \%(1)$ & $58 \%(85)$ & $41 \%(60)$ & $100 \%$ \\
\hline
\end{tabular}

Source: Processed by Researchers, 2020

The management support dimension refers to the level of individual belief that leaders in the organization are committed and support the implementation of changes as stated by Holt, et al., (2007). Based on the results of the survey that researchers conducted, the majority of Central Government Employee respondents showed relatively good confidence in the 
support given by the organization's leadership in supporting the policy of working from home as reflected in Table 5 above (High and Low Confidence of $48.9 \%$ ). While respondents of Regional government employees also had good confidence where only $1 \%$ of them doubted the support of the organization's leadership in supporting WFH.

Table 6.

The Different Test of Management Support of Central government employees and Regional government employees

\begin{tabular}{|l|l|}
\hline & Management Support Dimension \\
\hline Mann-Whitney U & 16097.000 \\
Wilcoxon W & 26828.000 \\
Z & -1.313 \\
Asymp. Sig. (2-tailed) & .189 \\
\hline
\end{tabular}

Source: Processed by Researchers, 2020

Based on this, it can be seen that the value of significance in the Management Support dimension is $0.189>0.05$ which means $\mathrm{H0}$ is not rejected; there is no difference in the confidence of Central government employees and Regional government employees in the Management Support dimension in implementing WFH. This occurs because the low, medium and high percentages in the Management Support dimension showed no significant difference. The absence of difference of belief between Central Government Employee respondents and Regional Government Employee respondents in the Management Support dimension becomes interesting. This is because in relation to the support of WFH implementation, it turns out that local agencies and central agencies both provide great support to support their employees in implementing WFH policy. Ashal (2020); Asbari, et al., (2020); Astuti \& Khoirunnisa (2018); Jumiran, et al., (2020) argue that organizational support and management support factors are very influential in employee's performance. Organizational support can be in the form of the provision of work facilities and infrastructure, the comfort of the work environment, as well as working conditions and management support in the form of support of management or leaders who are able to form a harmonious work system and be able to develop worker competencies, as well as provide motivation to employees (Ashal, 2020).

In terms of leadership support, reflecting from the collected responses for answering item number 12 concerning "The head of the agency I work for has fully supported the implementation of Work From Home (WFH)", as many as $69.2 \%$ or 101 respondents of 
Regional Government Employee "Agree" to the leadership of their agency working have fully supported the implementation of WFH, while the respondents of the Central Government Employee only 59.1\% or 140 respondents who "Agree" to it. On the other hand, still in the same question, as many as $16.9 \%$ or 40 Central Government Employee respondents felt "Strongly Agree" that their agency leadership gave full WFH implementation support, while in Regional Government Employee respondents only $6.2 \%$ or 9 respondents felt "Strongly Agree" about it.

Then, in terms of motivation given by the leader can be seen from the respondent's answer in question questionnaire item number 11 concerning "I get motivation from the head of the agency I work for to Implementing Work From Home (WFH)", 73.3\% or 107 respondents of the Regional Government Employee "Agreed" that they were motivated by the leadership of the agency they worked in implementing WFH, while the respondents of the Central Government Employee only 59.1\% or 140 respondents who "Agreed" on the issue. However, it was also found that Central Government Employee respondents answered "Strongly Agree", which is $13.1 \%$ or 31 respondents who were very confident that the leaders of the agencies they worked in provided motivation to implement WFH, while only $4.1 \%$ or 6 respondents of Regional Government Employee were "Strongly Agree" to it.

There is no difference of belief in the Management Support dimension in Central government employees and Regional government employees also seen from the open question of "Do the agencies in which you work provide support facilities for employees in implementing Work From Home (WFH)?". When viewed from the respondent's answer to the open question, there is not very significant difference, such as as $19.2 \%$ or 28 respondents of Regional Government Employee who answered getting supporting facilities from their agencies working in the form of supporting infrastructure, such as laptops, printers, and computers, while Central Government Employee respondents there were $18.1 \%$ or 43 respondents who got supporting infrastructure in implementing WFH.

Table 7.

Change-Specific Efficacy of Central and Regional Government Employees

\begin{tabular}{|l|l|l|l|l|}
\hline \multirow{2}{*}{$\begin{array}{l}\text { Government Agencies } \\
\mathrm{n}=383)\end{array}$} & \multicolumn{3}{|l|}{ Change-Specific Efficacy Dimension Level } & \multirow{2}{*}{ Total } \\
\cline { 2 - 4 } & Low & Moderate & High & \\
\hline
\end{tabular}




\begin{tabular}{|l|l|l|l|l|}
\hline $\begin{array}{l}\text { Central government employees } \\
(\mathrm{n}=237)\end{array}$ & $1 \%(2)$ & $48 \%(113)$ & $51 \%(122)$ & $100 \%$ \\
\hline $\begin{array}{l}\text { Regional government employees } \\
(\mathrm{n}=146)\end{array}$ & $2,1 \%(3)$ & $69,2 \%(101)$ & $28,7 \%(42)$ & $100 \%$ \\
\hline
\end{tabular}

Source: Processed by Researchers, 2020

According to Holt, et al., (2007), Change-Specific Efficacy refers to an individual's level of confidence that they have the ability and skills to carry out tasks and activities when changes are implemented. Based on the results of a research survey that can be seen in Table 7, in dimension Change-Specific Efficacy, the majority of respondents to the Central Government Employee in a row showed high confidence (51\%) and moderate (48\%) to learn the various skills necessary to implement WFH effectively. While the majority of Regional Government Employee respondents, in the context of potential self-development, have moderate confidence of $69.2 \%$ and are followed by those who are very optimistic $(28.7 \%)$. Employees who felt less confident in their ability to learn new skills were very few (2.1\%).

Table 8.

The Different Test of Change-Specific Efficacy of Central government employees and Regional government employees

\begin{tabular}{|l|l|}
\hline & Change-Specific Efficacy Dimension \\
\hline Mann-Whitney U & 13303.500 \\
Wilcoxon W & 24034.500 \\
Z & -4.395 \\
Asymp. Sig. (2-tailed) & .000 \\
\hline
\end{tabular}

Source: Processed by Researchers, 2020

Based on the table above, it is known that the significance of Mann Whitney U Test results between Central government employees variable and Regional government employees is $0.000<0.05$ on Change-Specific Efficacy dimension, so it can be concluded that $\mathrm{HO}$ is rejected; there is a difference in individual beliefs in the Change-Specific Efficacy dimension in implementing WFH between Central Government Employee respondents and Regional Government Employee respondents. Based on the results of the data process, it can be concluded that Central Government Employee respondents have a higher rate of ChangeSpecific Efficacy compared to respondents of Regional Government Employee.

The high confidence of Central Government Employee respondents is seen from the questionnaire answer on question item number 20 concerning "I feel I have sufficient skills in using digital devices to realize the successful implementation of Work From Home (WFH)", 
91.5\% or 217 Central Government Employee respondents (25.3\% or 60 respondents felt "Very Confident" and $66.2 \%$ or 157 respondents felt "Confident") stated that they had sufficient skills in using digital devices to realize the success of WFH implementation, while regional government employees only $79.5 \%$ or 116 respondents (5.5\% or 8 respondents who felt "Very Confident" and 74\% or 108 respondents felt "Confident") who felt that way. Then, judging by the questionnaire answer in item question number 19 concerning "I feel unable to complete the task properly when implementing Work From Home (WFH)", as many as $18.1 \%$ or 43 respondents of Central Government Employee "Very Do not" feel if they cannot complete the task properly when carrying out WFH, while Regional government employees only $4.1 \%$ or 6 respondents who "Strongly Do not" feel that way. This can be seen from the answer of Central Government Employee respondents who answered the open question of "Can working at home or out of the office affect work from home (WFH)?", where the majority (65\% or 154 respondents) answered working at home or outside the office did not affect WFH's work completion. This means that Central Government Employee respondents are very confident that they have the ability and skills to carry out tasks and activities when changes are implemented. It was also supported from the answers of Central Government Employee respondents, only $0.4 \%$ or 1 respondent had barriers regarding IT skills during WFH compared to Regional Government Employee respondents, namely 3.4\% or 5 respondents who had barriers in IT skills, such as stuttering technology and skills in using the application. This can be seen for example in teachers (Regional Civil Servants) in SD Negeri Dengkek 01 Pati where there are still teachers in the school who are less good at technology in conducting the learning process (Rokhani, 2020).

In addition, when compared to ICT literacy among Central government employees and Regional government employees, Central government employees have better ICT literacy compared to Regional government employees. Although the Lembaga Administrasi Negara (LAN) does not yet have ICT literacy data among civil servants nationally (Arrochmah \& Nasionalita, 2020), but based on previous studies such as Kanter, et al. (2019), ICT literacy among civil servants of Gorontalo regency is generally still in the category of beginners or relatively low, and Ngantung, et al. (2014) stated that the literacy rate of ICT of Manado City as a whole is classified into a low category. Meanwhile, the digital literacy of civil servants in 
the Ministry of Communication and Informatics (KOMINFO) is classified as good (Rumata \& Nugraha, 2020).

Table 9.

Personal Valence of Central and Regional Government Employees

\begin{tabular}{|l|l|l|l|l|}
\hline \multirow{2}{*}{$\begin{array}{l}\text { Government Agencies } \\
(\mathrm{n}=383)\end{array}$} & \multicolumn{3}{|l|}{ Personal Valence Dimension Level } & Total \\
\cline { 2 - 4 } & Low & Moderate & High & \\
\hline $\begin{array}{l}\text { Central government employees } \\
(\mathrm{n}=237)\end{array}$ & $7,6 \%(18)$ & $71,7 \%(170)$ & $20,7 \%(49)$ & $100 \%$ \\
\hline $\begin{array}{l}\text { Regional government employees } \\
(\mathrm{n}=146)\end{array}$ & $12 \%(17)$ & $82 \%(120)$ & $6 \%(9)$ & $100 \%$ \\
\hline
\end{tabular}

Source: Processed by Researchers, 2020

The Personal Valence dimension according to Holt, et al., (2007) is an individual's belief that the proposed changes benefit individuals personally. As summarized in Table 9 above, as many as $20.7 \%$ of Central Government Employee respondents have high confidence in the benefits they can get by supporting the implementation of Work from Home policy. Meanwhile, $71.7 \%$ of them had moderate confidence, and the remaining $7.6 \%$ showed low level confidence in the potential benefits they could get from the WFH Policy. When compared to Regional Government Employee respondents, only 6\% of them had high confidence in the benefits they would get by supporting WFH. While $82 \%$ have moderate confidence, only $12 \%$ of them doubt the potential benefits of implementing the Work From Home Policy.

Table 10.

The Different Test of Personal Valence of Central government employees and Regional government employees

\begin{tabular}{|l|l|}
\hline & Personal Valence Dimension \\
\hline Mann-Whitney U & 14425.500 \\
Wilcoxon W & 25156.500 \\
Z & -3.646 \\
Asymp. Sig. (2-tailed) & .000 \\
\hline
\end{tabular}

Source: Processed Research Results, 2020

Based on table 10, it can be seen that the value of significance in the Personal Valence dimension is $0.000<0.05$ which means $\mathrm{H} 0$ is rejected; there is a difference in the readiness of Central Government Employee and Regional Government Employee respondents in the Personal Valence dimension in implementing WFH. This is because the percentage of 
readiness of Central Government Employee respondents in the Personal Valence dimension is higher than that of Regional Government Employee respondents which is $20.7 \%$ or 49 respondents compared to $6 \%$ or 9 respondents.

The level of individual confidence that the proposed changes are beneficial to the individual is one thing to note. Based on the respondent's answer based on questionnaire question number 35 which is "Do you feel personal relationship with colleagues become stretched when carrying out WFH?". Central Government Employee respondents showed the majority as much as $57 \%$ or 135 respondents "Disagreed" that the implementation of WFH made personal relationships with colleagues difficult. On the other hand, respondents of the Regional Government Employee majority think the same as the respondents as much as 56\% or 82 respondents answered "Disagree" that in the implementation of WFH make the relationship with colleagues become stretched. This is reinforced by Gajendran \& Harrison's (2007) opinion that the implementation of WFH does not have a bad impact on inter-personal relationships in the workplace.

The Personal Valence dimension also encompasses the implementation of WFH may cause fear that individuals will lose social status in working agencies. Related to that, there is a questionnaire question number 36 which is "Are you worried about losing social status in the agency where you work during the implementation of WFH" in which the majority of Central Government Employee as much as 69\% or 164 respondents answered "Disagree" that the implementation of WFH raised fears that individuals would lose social status in the agencies where it worked. Then, for Regional Government Employee respondents to have something in common, the majority answered "Disagree" that the implementation of WFH makes worrying about losing social status in the agency where it works.

McCloskey \& Igbaria (2003) argues that concerns from individuals may arise in carrying out tasks remotely which can be a concern for career prospects in the workplace. Related to this, questionnaire question number 37 is "whether WFH can limit career levels in workplace agencies" where the majority of Central Government Employee as much as $71 \%$ or 169 respondents "Disagree" that the implementation of work in a WFH way can limit the career level of the individual in the institution in which he or she works. While for Central Government Employee respondents the majority had the same answer, which is shown with 
as many as $81 \%$ or 118 respondents answering "Disagree" that the implementation of WFH can limit the career level of the individual in the institution in which he or she works.

On the other hand, based on questionnaire question number 40 is an open question namely "Is there any difficulty in establishing good communication with the internal parties of the organization when the implementation of WFH?". It turns out that the majority of Central Government Employee as much as $77 \%$ or 182 respondents when running WFH answered "Do not" having difficulty in establishing good communication with internal parties of the organization. Then for Regional Government Employee respondent, the majority of them, as many as $68 \%$ or 99 respondents answered the same thing that is "no" having difficulty in establishing good communication with internal organizations during the implementation of WFH. However, there were findings in the Central Government Employee as many as 23\% or 55 respondents and as many as 32\% or 46 respondents of Regional Government Employee answered that in the implementation of WFH answered "Do" had difficulty in establishing good communication with internal parties of the organization. These difficulties are due to several factors such as miscommunication, stunted communication, work to be done in the office, lack of technology savvy, slow response and limitations of technology and network.

Then for the open question namely question questionnaire number 38 is an open question namely "Do you have any obstacles in completing the work WFH?" the majority of Central Government Employee as much as 65\% or 153 respondents answered "Do not" has obstacles in completing the work on a WFH. Then, for Regional Government Employee respondents, the majority have the same answer that the implementation of WFH "Does not" impede individuals in completing the work of $62 \%$ or 90 respondents. However, as many as 35\% or 84 respondents of Central Government Employee answered "Yes" that WFH hindering individuals from completing their work. On the other hand, Regional Government Employee as many as 385 or 56 respondents chose to answer "Yes" that experienced obstacles in completing the work in WFH due to several factors such as internet network constraints, lack of supporting facilities, environmental conditions, costs, need for adaptation process, and coordination problems.

\section{Summary}

The findings in this study are that there is a difference in readiness between central government employee and regional government employee respondents in implementing 
WFH policy. Based on the analysis, the central government employee respondents have a statistically better level of readiness than regional government employee respondents. Statistically, central government employee respondents possess better level of understanding of the urgency to change the way of working from conventional to the WFH than their colleagues at the local level. In addition, respondents from central government are also superior in perceiving potential benefit for individuals and organizations. Moreover, central government employee respondents have a higher level of confidence in learning new skills supporting WFH and awareness of the potential benefits of WFH for themselves personally than regional government employee respondents. This is reinforced by the findings of central government employee respondents who have higher confidence in accomplishing the required tasks amidst WFH than their colleagues working at the regional level. In addition, it is also important to note that ICT literacy rates among central government employee respondents are higher than those of regional government employee respondents.

On the other hand, central government employee respondents have a higher level of confidence than regional government employee respondents that various personal benefits will be enjoyed following the implementation of WFH policy. It is evidenced among respondents from central governments that the change from conventional way of work to WFH does not significantly affect personal relationships with colleagues. In addition, majority of central government officers who participated in this study do not worry about losing social status if they support WFH. Besides that, central government employee respondents also show their superiority above regional government employee respondents regarding the possible impact of WFH to their individual career prospects. However, in terms of managerial support, there is no significant difference between central and regional government employee respondents.

The implementation of WFH during the pandemic in general did not create severe problems for both central and regional government employee respondents. The government may consider to prolong the application of WFH's workings among civil servants even after the pandemic ends with a number of improvements and clear objectives. 


\section{Acknowledgements}

We thank our colleagues from the Research Method Class 2020/2021, Faculty of Administrative Science Universitas Indonesia for allowing us to use and further analyze the online survey data as the basis for this article.

\section{References}

\section{Journal}

Abdurrohman, M. F., \& Kadiyono, A. L. (2019). Getting Prepared: Employee Readiness for Changes. Conference Paper.

Arrochmah, N. P., \& Nasionalita, K. (2020). Kesenjangan Digital Antara Generasi X dan Y di Pemerintah Provinsi DKI Jakarta. Diakom: Jurnal Media dan Komunikasi, 26-39.

Ammons, S. K., \& Markham, W. T. (2010). Working at Home: Experiences of Skilled White Collar Workers. Sociological Spectrum.

Armenakis, A. A., \& Harris, S. G. (2002). Crafting a change message to create transformational readiness. Journal of Organizational Change Management, 169-183.

Asbari, M., Fayzhall, M., Goestjahjanti, F. S., Winanti, Yuwon, T., Hutagalung, D., . . . Purwanto, A. (2020). Peran Kepemimpinan Transformasional dan Organisasi Pembelajaran terhadap Kapasitas Inovasi Sekolah. EduPsyCouns Journal, 122-145.

Ashal, R. A. (2020). Effect of Work from Home on State Civil Apparatus Performance at Special Class I Immigration Office TPI Medan. Jurnal Ilmiah Kebijakan Hukum, 223242.

Astuti, E., \& Khoirunnisa, R. M. (2018). Pengaruh Employee Engagement, Komitmen Organisasi, dan Kepemimpinan Transformasional terhadap Kesiapan untuk Berubah (Readiness for Change) pada Karyawan Universitas Ahmad Dahlan. Jurnal Fokus, 47-66.

Baruch, Y. (2002). Teleworking: benefits and pitfalls as perceived by professionals and managers. New Technology Work and Employment, 34-49.

Cooper, C. D., \& Kurland, N. B. (2002). Telecommuting, Professional Isolation, and Employee Development in Public and Private Organizations. Journal of Organizational Behavior , 511-532. 
Fonner, K. L., \& Roloff, M. E. (2010). Why Teleworkers are More Satisfied with Their Jobs than are Office-Based Workers: When Less Contact is Beneficial. Journal of Applied Communication Research.

Gajendran, R. S., \& Harrison, D. A. (2007). The Good, the Bad, and the Unknown About Telecommuting: Meta-Analysis of Psychological Mediators and Individual Consequences. Journal of Applied Psychology, 1524-1541.

Handy, S. L., \& Mokhtarian, P. L. (1996). The Future of Telecommuting. Pergamon.

Hanpachern, C., Morgan, G. A., \& Griego, O. V. (1998). An Extension of the Theory of Margin: A Framework for Assessing Readiness for Change. Jossey-Bass Publishers, 339-350.

Holt, D. T., Armenakis, A. A., Feild, H. S., \& Harris, S. G. (2007). Readiness for Organizational Change: The Systematic Development of a Scale. The Journal of Applied Behavioral Science Vol. 43 No. 2, 232-255.

Holt, D. T., Helfrich, C. D., Hall, C. G., \& Weiner, B. J. (2010). Are You Ready? How Health Professionals Can Comprehensively Conceptualize Readiness for Change. Journal of General Internal Medicine Vol 25. No.1, 50-55.

Holt, D. T., \& Vardaman, J. M. (2013). Toward a Comprehensive Understanding of Readiness for Change: The Case for an Expanded Conceptualization. Journal of Change Management Vol. 13 No. 1, 9-18.

Ipsen, C., \& Kirchner, K. (2020). Experiences of Working From Home in Times of COVID-19 International Survey Conducted the First Months of the National Lockdowns. DTU Management, 1-32.

Jumiran, Novitasari, D., Nugroho, Y. A., Sutardi, D., Sasono, I., \& Asbar, M. (2020). Pengaruh Dimensi Kepemimpinan Transformasional terhadap Kepuasan Kerja dan Komitmen Organisasional: Studi Kasus pada Dosen Perguruan Tinggi Swasta. Journal of Education, Psychology and Counseling, 600-621.

Kanter, C. H., Kenda, N., Umboh, F. F., \& Amali, S. (2019). Tingkat Literasi TIK ASN Kabupaten Gorontalo. Prosiding Seminar Nasional 2019, 205-216.

Khalifa, M., \& Davison, R. (2000). Exploring the Telecommuting Paradox. Communications of the ACM. 
McCloskey, D. W., \& Igbaria, M. (2003). Does “out of sight" mean “out of mind"? An empirical investigation of the career advancement prospects of telecommuters. Information Resources Management Journal, 16(2), 19-34.

Morgan, R. E. (2004). Teleworking: an assessment of the benefits and challenges. European Business Review.

Mungkasa, O. (2020). Bekerja dari Rumah (Working From Home/WFH): Menuju Tatanan Baru Era Pandemi COVID 19. The Indonesian Journal of Development Planning Volume IV No. 2 , 126-150.

Mustajab, D., Bauw, A., Rasyid, A., \& Irawan, A. (2020). Working from Home Phenomenon as an Effort to Prevent COVID-19 Attacks and Its Impacts on Work Productivity. The International Journal of Applied Business.

Ngantung, D. R., Lumenta, A. S., \& Karouw, S. D. (2014). Analisa Literasi TIK Aparatur Sipil Negara (ASN) Pemerintah Kota Manado. Jurnal Teknik Informatika , 1-8.

Rigianti, H. A. (2020). Kendala Pembelajaran Daring Guru Sekolah Dasar di Kabupaten Banjarnegara. Elementary School 7, 297-302.

Rokhani, C. T. (2020). Pengaruh Work From Home (WFH) Terhadap Kinerja Guru SD Negeri Dengkek 01 Pati Selama Masa Pandemi Covid-19. Journal of Education, Psychology and Counseling, 424-437.

Rumata, V. M., \& Nugraha, D. A. (2020). Rendahnya tingkat perilaku digital ASN kementerian kominfo: Survei literasi digital pada instansi pemerintah. Jurnal Studi Komunikasi, 467-484.

Suarlan. (2018). Teleworking for Indonesia Civil Servants: Problems and Actors. Bisnis $\mathcal{E}$ Birokrasi Journal, 100-109.

Taufik, \& Warsono, H. (2020). Birokrasi Baru untuk New Normal: Tinjauan Model Perubahan Birokrasi dalam Pelayanan Publik di Era COVID-19. Dialogue Jurnal Ilmu Administrasi Publik, 1-18.

Vakola, M. (2014). What's in there for me? Individual readiness to change and the perceived impact of organizational change. Leadership \& Organization Development Journal Vol. 35 No. 3, 195-209.

Van de Ven, A. H., \& Poole, M. S. (1995). Explaining Development and Change in Organizations. Academy of Management Review Vol. 20 No. 3, 510-540. 
Vries, H. d., Tummers, L., \& Bekkers, V. (2019). The Benefits of Teleworking in the Public Sector: Reality or Rhetoric? Review of Public Personnel Administration, 570-593.

Wilson, M., \& Greenhill, A. (2004). Gender and teleworking identities in the risk society: a research agenda. New Technology Work and Employment, 207-221.

Yulianto. (2020). Meningkatkan Kompetensi Aparatur Sipil Negara Dalam Pelayanan Publik Menuju Era New Normal. Prosiding Seminar Stiami Volume 7, No. 2, 36-45.

\section{Book}

Badan Kepegawaian Negara. (2020). Buku Statistik Pegawai Negeri Sipil Juni 2020. Jakarta: Badan Kepegawaian Negara.

East Ventures. (2020). East Ventures Digital Competitiveness Index 2020. Jakarta: East Ventures.

Gurstein, P. (2001). Wired to the World, Chained to the Home: Telework in Daily Life. Vancouver: UBC Press.

Paudel, N. R. (2020). COVID 19 Outbreak and Impact on Governance System. Nepal: Society of Management and Governance Policy Research Center (SOMAG-PRC).

\section{Website}

Fajar, T. (2019, Agustus 08). Kemenpan RB Wacanakan PNS Bisa Kerja di Rumah. Retrieved from economy.okezone.com:

https://economy.okezone.com/read/2019/08/08/320/2089595/kemenpan-

rb- wacanakan-pns-bisa-kerja-di-rumah

HUMAS MENPAN-RB. (2019, Agustus 09). Menciptakan Smart ASN Menuju Birokrasi 4.0. Retrieved from menpan.go.id: https://www.menpan.go.id/site/beritaterkini/menciptakan-smart-asn-menuju-birokrasi-4-0

Kemp, S. (2020). Digital 2020: Indonesia. We Are Social Inc. https://datareportal.com/reports/digital-2020-indonesia

Krisyohana, M. (2020, Juni 11). Kesiapan Manajemen ASN untuk WFH. Diambil kembali dari detiknews: https://news.detik.com/kolom/d-5049198/kesiapan-manajemen-asnuntuk-wfh

Mukaromah, V. F. (2019, November 23). Pro Kontra Wacana ASN Bisa Kerja dari Rumah. Retrieved from kompas.com: https://www.kompas.com/tren/read/2019/11/23/200000265/pro-kontra-wacana-asnbisa-kerja-dari-rumah?page=all 
Sukmana, Y. (2019, Agustus 08). Kemenpan RB Susun Rencana agar PNS Bisa Kerja dari Rumah. Retrieved from money.kompas.com: https://money.kompas.com/read/2019/08/08/163300026/kemenpan- $\quad$ rb-susunrencana-agar-pns-bisa-kerja-dari-rumah?page=all

Ulya, F. N. (2019, November 20). Tahun Depan, Bappenas Uji Coba 1.000 ASN Tak Perlu Kerja di Kantor. Retrieved from money.kompas.com: https://money.kompas.com/read/2019/11/20/151800326/tahun-depan-bappenas-ujicoba-1000-asn-tak-perlu-kerja-di-kantor?page=all

Wardhana, I. W. (2020, Mei 28). "Work from Home" Selamanya? Retrieved from news.detik.com: https://news.detik.com/kolom/d-5031726/work-from-home-selamanya 